\title{
The benefits of progesterone therapy in imminent abortion
}

\author{
A. Abadi, Ali Baziad, Andon Hestiantoro
}

\begin{abstract}
Abstrak
Penyebab abortus iminens multifaktor. Penyebab terbesar adalah rendahnya kadar progesteron serum. Kadar kritis terendah progesteron serum untuk kelangsungan kehamilan adalah $10 \mathrm{ng} / \mathrm{ml} .80 \%$ pasien yang mengalami abortus kadar progesteronnya berada < $10 \mathrm{ng} / \mathrm{ml}$. Pasien yang mengetahui kehamilannya mengalami perdarahan umumnya akan mengalami stress. Stress merupakan juga salah satu faktor terjadinya abortus. Pemberian substitusi progesteron alami (bukan progestogen) mempercepat hilangnya kontraksi uterus, dan mempercepat hilangnya perdarahan. Selain itu progesteron juga memiliki khasiat antikecemasan. Pemberian progesteron oral akan mengalami metabolisme di usus dan hati, sehingga tidak dapat dicapai kadar progesteron serum yang fisiologis, sedangkan pemberian progesteron supositoria diperoleh kadar serum yang fisiologik sehingga sangat efektif mencegah abortus iminens. (Med J Indones 2005; 14:258-62)
\end{abstract}

\begin{abstract}
The causes of imminent abortion are multi-factorial. The biggest causal factor is the low level of serum progesterone level. The lowest critical level of serum progesterone for survivability of pregnancy is $10 \mathrm{ng} / \mathrm{ml}$. Eighty percent of patients experiencing abortion showed that their progesterone level was $<10 \mathrm{ng} / \mathrm{ml}$. Patients who realized that their pregnancy would experience hemorrhage generally would suffer from depression. Stress was one of the factors responsible for the occurence of abortion. Administration of natural progesterone substitution (not progestogen) accelerates the disappearance of uterine contractions, and speeds up the stoppage of bleeding. In addition, progesterone has the effect of anti-anxiety. Adminstration of oral progesterone would result in metabolism in the intestine and liver, such that physiological level of serum progesterone could not be reached, while administration of suppositoria progesterone would result in physiological level of serum, such that it was effective to prevent imminent abortion. (Med J Indones 2005; 14:258-62)
\end{abstract}

Keywords: progesterone, imminent abortion

Imminent abortion is indicated by vaginal bleeding before 20 weeks of pregnancy, without pain and the size of uterus is compatible with pregnancy age and the closed cervix. The incidence rate of this type of abortion ranged between 16 and $21 \%$.

The causes of imminent abortion are multi-factorial, such as fetal factor, maternal factor, and paternal factor. Maternal factors that may lead to imminent abortion include infection, chronic disease, hormonal abnormality, use of drugs, and environmental factor. Hormonal abnormality contributes most to the causes of imminent abortion, i.e. 35-50\%. ${ }^{1}$ Progesterone hormone is extremely important in maintaining the

\footnotetext{
* Division of Reproductive Immunoendocrinology, Department of Obstetrics and Gynecology Faculty of Medicine, University of Indonesia/Dr. Cipto Mangunkusumo Hospital, Jakarta, Indonesia
}

survivability of pregnancy. Progesterone works to maintain pregnancy and delay childbirth by inhibiting uterine contractions, and increasing the sensitiveness of uterine muscles toward relaxin hormone. In addition, progesterone has a sedative effect such that patients become relaxed. ${ }^{2}$ Patients with imminent abortion normally experience severe distress, and during distress adrenaline could be released in large amount. Adrenaline causes vasoconstriction of blood vessels, such that oxygenation in fetus may reduce. If placenta experiences hypoxia, body will produce CRF in large amount and as a result uterine contractions occur. ${ }^{3}$ Glucocorticoid, prostaglandin, cytokin, and adrenaline could trigger the secretion of CRF in placenta.

Progesterone is produced by corpus luteum until early pregnancy of seven weeks, and if corpus luteum is removed, miscarriage will ensue. After seven weeks of pregnancy, placenta replaces the function of corpus luteum in producing progesterone. In early pregnancy, 
at least $5.1 \mathrm{ng} / \mathrm{ml}$ of progesterone level is needed in blood in order that pregnancy could survive appropriately. However, if progesterone serum level is found at $>25 \mathrm{ng} / \mathrm{ml}$, almost $97 \%$ of pregnancies could develop safely. ${ }^{1,4,5,6,7}$ If during the first trimester of pregnancy, serum progesterone level is found less than 18.9 $\mathrm{ng} / \mathrm{ml}$, the risk of failure for such pregnancy is 4.6 times as high. ${ }^{1,5}$ The administration of progesterone accelerates the disappearance of uterine contractions, and speeds up the stoppage of bleeding. ${ }^{4,8,9}$

Prior to the arrival of progesterone, treatment of imminent abortion was performed by administering progestogen tablets, such as alilestrenol. The administration of progestogen tablet orally resulted in several problems, such as gastrointestinal disorder and rapid metabolism in the intestine and liver, such that an optimal level of serum progesterone could not be reached. Moreover, progesterone of this type was not genuinely pure as that produced by corpus luteum. In order to prevent metabolism in the intestine and liver appropriately, suppository progesterone has been developed, which can be administered vaginally. Since it does not undergo metabolism in the intestine and liver, an optimal level of serum progesterone can be achieved. This suppository progesterone was derived from pure progesterone, such as one produced by corpus luteum and placenta.

\section{Progesterone in imminent abortion}

In pregnancy age of 0-20 weeks with progesterone level of $<10 \mathrm{ng} / \mathrm{ml}$, prognosis of pregnancy is unfavorable, or $80 \%$ of pregnant women will experience abortion. ${ }^{1,4,10}$ Progesterone can be administered orally, by injection, or by suppository. Oral administration of progesterone will result in metabolism in the intestine and liver, such that progesterone level in the serum becomes insufficient to maintain the survivability of pregnancy. ${ }^{4,11,12}$ The administration of progesterone by suppository, either vaginally or orally, could result in the physiological serum level, and even in a very high level. Both vaginal and rectal mucosas do not have enzyme that can metabolize progesterone, such that no changes occur in the active agent of progesterone. The administration of 100-400 mg progesterone (Cyclogest), either rectally or vaginally, resulted in the serum progesterone level as high as progesterone level in luteal phase.

\section{Immunology of imminent abortion}

Immunologically, progesterone triggers the formation of progesterone-induced blocking factor (PIBF) and cadherine. (Figure 1).,13,14

PIBF inhibits the activity of natural killer cell (NKC) which in vitro has proved to be able to prevent the abortive effect of NKC on rats. In imminent abortion, an increase in NKC activity was observed.

In spontaneous abortion, an increase in cytokine production produced by $\mathrm{T}$ cell helper 1 (Th 1) was found. This cytokine is cytotoxic, such as interleukin-2 (IL-2) and interferon-Y (IFN-Y), and tumor necrosis factor$\beta$ (TNF- $\beta$ ). T helper-2 (Th-2) produces IL-4, IL-6, IL5 and IL-10, which are very beneficial in maintaining the survivability of pregnancy. Thus, whether a pregnancy can survive or not greatly depends on the balance of Th-1 and Th-2.

Cadharine is an adhesive protein. The function of endometrium largely depends on the availability of adhesive protein. This protein plays a major role in the process of embryo implantation in the endometrium. ${ }^{3}$ Progesterone triggers the formation of cadharine. If progesterone level is not sufficient, the production of cadharine will decrease correspondingly, and with it the breakdown of endometrial cells will occur, and finally the process of embryogenesis will be disrupted. Progesterone suppresses the production of TNF- $\alpha$. If progesterone level decreases, the production of TNF- $\alpha$ will increase, and this TNF- $\alpha$ will enhance the apoptosis of endometrial cells and change vascular integrity, such that the density of endometrial cells will decrease. Cadherine consists of several types, i.e. cadherine-E which is frequently found in the endometrium, cadherine- $P$ in the heart, lung, and intestines, cadherine- $\mathrm{N}$ in the central nerves and mesoderm, cadherine$\mathrm{R}$ in the retina and glial cells, and cadherine- $\mathrm{M}$ in the myoblast cells.

\section{Progesterone and anxiety}

Pregnant women experiencing bleeding are generally stressful, particularly those who have intensely wanted to have children. Anxiety has the effect not only on that woman, but also on the fetus. In pregnant women, stress causes the production of adrenaline and noradrenaline. These two types of hormone may cause vasoconstriction of placental blood vessels, such that 


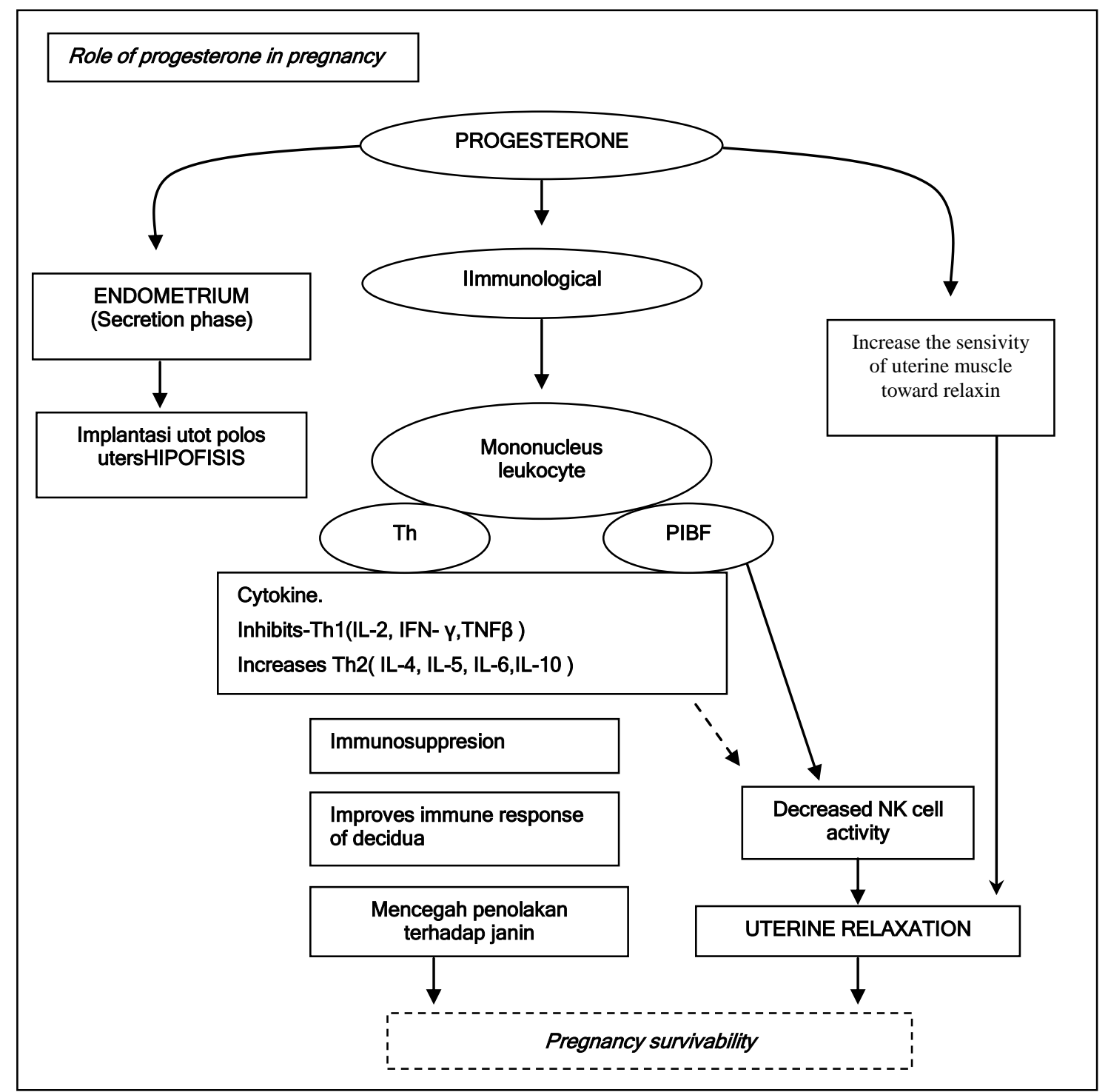

Figure 1. The role of progesterone in pregnancy; Endometrium phase of secretion, preparing implantation; Immunological: by cytokine the prevention is turned into inhibiting of $N K$ cell activity, the sensitiveness of uterine muscle toward relaxin is increased

hypoxia in the fetus may occur. In a hypoxic state, placenta produces corticosteroid-release hormone (CRF). Paracrine CRF acts toward decidua and myometrium, and increases the production of prostaglandin, and as a result the contraction of uterine muscle is increased. Hypoxia is censor for placenta to secrete CRF. CRF receptor is also found in the endometrium, which is beneficial for synthesizing prostaglandin and strengthening oxytocin effect. Glucocorticoid, prostaglandin, cytokine, and catecholamine increases the secretion of CRF in placenta, while NO inhibits the secretion of CRF.

\section{Progesterone and anxiety}

Pregnant women experiencing bleeding are generally stressful, particularly those who have intensely wanted to have children. Anxiety has the effect not only on that woman, but also on the fetus. In pregnant women, stress causes the production of adrenaline and noradrenaline. These two types of hormone may cause vasoconstriction of placental blood vessels, such that hypoxia in the fetus may occur. In a hypoxic state, placenta produces corticosteroid-release hormone (CRF). Paracrine CRF acts toward decidua and myometrium, 
and increases the production of prostaglandin, and as a result the contraction of uterine muscle is increased. Hypoxia is censor for placenta to secrete CRF. CRF receptor is also found in the endometrium, which is beneficial for synthesizing prostaglandin and strengthening oxytocin effect. Glucocorticoid, prostaglandin, cytokine, and catecholamine increases the secretion of CRF in placenta, while NO inhibits the secretion of CRF.

Progesterone has anti-stress effect on the central nervous system. In its work to overcome stress, progesterone uses certain mediators. One of the extremely mediators is ỳ butyric amino acid (GABA-A). ${ }^{15}$ Progesterone and its metabolic, along with barbiturate and benzodiazeoin, could occupy GABA-A. Through activation of GABA-A receptor, progesterone has its sedative effect. One of the progesterone metabolites, $5 \alpha-$ pregnan-3 $\alpha-\mathrm{Ol}, 20$ ( $3 \alpha-\mathrm{OH} \mathrm{DHP}$ ), possesses sedative effect eight times as strong as barbiturate. ${ }^{2}$ In addition to anti-stress effect, GABA-A possesses hypnotic and anti-convulsant effects. Biological effect of GABA-A receptor follows circadian mechanism. At night, progesterone exerts sedative effect, while in daytime it has the effect of stimulating GABA-A receptor. Highdose calcium triggers the secretion of GABA-A and nerve cells.

Glycine is also a sedative mediator for the central nervous system. If progesterone possesses the effect of activating GABA-A receptor, such that it has sedative effect, progesterone on the other hand has the effect inhibiting the activity of glycine. Progesterone is quite different from progestogen in terms of the sedative effect on the central nervous system. Progestogen, particularly its metabolite, has no ability to occupy GABA-A receptor, such that it does not have sedative effect. This is the reason why synthetic progestogen that has up to now been used in the treatment of imminent abortion was not effective compared with progesterone. Occasionally, synthetic progestogen may even cause excessive anxiety. ${ }^{3}$

The brain, particularly glial cells, is able to provide progesterone for the needs of its activities. In other words, glial cells have the ability to synthesize progesterone. With the aid of $3 \beta$-hydroxysteroid dehydrogenase enzyme, glial cells change pregnenolon into progesterone, and futhermore through $5 \alpha$-reductase enzyme assisted again by $3 \beta$-hydroxysteroid dehydrogenase enzyme, progesterone metabolites are formed that are very potent in occupying GABA-A receptor.

\section{CONCLUSIONS}

The administration of suppository progesterone resulted in a physiological level of serum progesterone, such that it was very effective in the treatment of imminent abortion. Up to now, the administration of progesterone-derived progestogen orally used in the treatment of imminent abortion has not reached a physiological level of serum progesterone. Natural progesterone, particularly its metabolites, has the sedative effect on the central nervous system, such that it could eliminate anxiety of pregnant women with imminent abortion. On the other hand, progesteronederived progestogen and its metabolites do not have such sedative effects.

\section{REFERENCES}

1. Cunningham FG, Gant NF, Leveno KJ, Gilstrap LC, Hauth JC, Wenstrom KD. Williams Obstetrics. 21 th ed. New York. Mc Grow-Hill. 2001: 855-81.

2. Norbeg L, Wahlstrom G, Backstrom T. The anaesthetic potency of $3 \alpha$-hydroxyl-5 $\alpha$-pregnan-20-one and $3 \alpha$ hydroxyl-5 $\beta$-pregnan 20-one determined with an intravenous EEG threshold method im male rats. Acta Pharma col Toxicol Scand 1987;61: 42-7

3. Huber J. Endokrine Gynakologie. Verlag Wilhelm Maudrich. Wien-Munchen-Bern. 1998:64-102

4. Satorriadis A, Papatheodore S, Makrydimas G. Threatened miscarriage: evaluation and management. BMJ 2004; 39:152-55

5. Jacoeb TZ. Nasib Kehamilan Triwulan Pertama: Manfaat penentuan Progesteron dan Antibodi Antikardiolipin Serum. Prosiding Simposium Temu Ilmiah Akbar 2002. FKUI, Jakarta 2002: 93-125

6. Daya S. Efficacy of progesterone support for pregnancy in women with recurrent miscarriage. A meta-analysis of controlled trials. B J Obstet Gynaecol 1989;96:275-80

7. Posaci C, Smitz J, Camus M, Osmanagaoglu K, Devroe J. Progesterone for the luteal support of assisted reproductive technologies: Clinical Options. J Hum Reprod 2000;15: 129-48

8. Gerhard I, Gwinner B, Eggert-Kruse W, Runnenbaum B. Double-blind controlled trial of progesterone substitution in threatened abortion. J Biol Res Pregnancy Perinatol 1987:8:26-34

9. Bulleti C, Ziegler De D, Maini M, Ferro ED, Polli V, Flamigni C. Effects of vaginal progesterone gel crinone $8 \%$ on uterine cramps and bleeding associated with threatened abortion. J Fertil Steril 2001;76: 184

10. Bulleti C, De Ziegler D, Flagmini C, Giagomucci E, Polli V, Franceschetti F. Targeted drug delivery in gynecology: the first uterine pass effect. J Hum Reprod 1997;12. 1073-79

11. Gucer F, Balkanli-Kaplan P, Yuksel M, Sayin NC, Yuce A., Yardim T. Maternal serum level of tumor necrosis factor- $\alpha$ and interleukin -2 receptor in threatened abortion: a comparison with normal and pathologic pregnancies. J Fertil Steril 2001;76:707-11 
12. Ludwig M, Finas A, Katalinic A, Strik D, Kowalcek I, Schwatzt $\mathrm{P}$ et al. Prospective, randomized study to evaluate the success rates using hCG, vaginal progesterone or a combination of both for luteal phase support. J Acta Obstet Gynecol Scand 2001;80: 574-82

13. Bartho JS, Faust Z, Varga P. The expression of progesterone-induced imunomodulatory protein in pregnancy lymphocytes. A J Reprod Immunol 1995;34:342-48
14. Folgar B, Kispal G, Lachmann M, Paar G, Nagy E, Csere P et al. Molecular cloning and immunologig characterization of a novel cDNA coding for progesterone-induced blocking factor. J Immun 2003;171: 5956-63

15. Majewska MD, Harrison N, Shwartz R, Barker J, Paul S. Steroid hormone metabolites are barbiturate-like modulators of the GABA receptor. Science 1986;232;1004-7 